\title{
Parasitic communities of Hoplosternum littorale (Hancock, 1828) as indicators of environmental impact
}

\author{
KARINA G.A DIAS ${ }^{1}$, CARLOS A. ALVES ${ }^{1}$, REINALDO J. DA SILVA ${ }^{1}$, \\ VANESSA D. ABDALLAH ${ }^{2}$ and RODNEY K. DE AZEVEDO \\ ${ }^{1}$ Instituto de Biociências de Botucatu, Departamento de Parasitologia, Universidade Estadual Paulista "Júlio \\ de Mesquita Filho", Rua Prof. Dr. Antônio Celso Wagner Zanin, s/n, 18618-689 Botucatu, SP, Brazil \\ ${ }^{2}$ Universidade do Sagrado Coração, Central de Ciência e Tecnologia Ambiental, \\ Rua Irmã Arminda, 10-50, 17011-160 Bauru, SP, Brazil
}

Manuscript received on November 14, 2016; accepted for publication on June 14, 2017

\begin{abstract}
The parasites are indicative of several biological aspects of their hosts, including their diet, migration, recruitment and phylogeny, but they can also be direct indicators of the environmental quality. Hoplosternum littorale is a fish that has a high commercial value in some South American countries. The fishes were collected from January to July 2012, in two locations of the Peixe River in the municipality of Anhembi, State of São Paulo, Brazil, which had different environmental and limnological characteristics (river mouth and Lagoa Cabeça de Boi). An amount of 30 fish specimens were captured in each location for the analysis of their parasitic fauna. Nine species of metazoan parasites were collected. Both Brillouin`s diversity index and Margalef"s richness index were greater in the Lagoa Cabeça de Boi. The ratio of heteroxenous and monoxenous parasite species richness $\left(\mathrm{S}_{\mathrm{H}} / \mathrm{S}_{\mathrm{M}}\right)$ was higher in the Lagoa Cabeça de Boi. The results of the physicochemical analysis of the water showed that the mouth of the Peixe River can be considered an area that suffers more from anthropogenic actions than the Lagoa da Cabeça de Boi. Proteocephalus sp., Gyrodactylus sp., Scleroductus sp. and Capillaria (Neocapillaria) pterophylli are being registered for the first time in this host.
\end{abstract}

Key words: bioindicators, Callichthyidae, parasites, Peixe River, São Paulo.

\section{INTRODUCTION}

Hoplosternum littorale (Hancock, 1828) is a fish whose common name is Tamboatá, a representative of the Order Siluriformes and Family Callichthyidae, presents a demersal habit, with a one-meter-depth range, fresh water fish from tropical environments (Nico et al. 1996).

Correspondence to: Vanessa Doro Abdallah

E-mail: vanessaabdallahusc@gmail.com
This species has a high commercial value in some South American countries and it presents an easy reproduction in confined environments and a good tolerance to low levels of oxygen, which makes them favorable for the cultivation (Luquet et al. 1990). It has a sub-terminal mouth; its body is ventrally flat and covered by bone plates, which enables us to infer that this species is little agile, having a twilight-night food life cycle to avoid the predation by large piscivorous (Reis 1997). 
According to Hahn et al. (1997), the H. littorale is a species with a large eating variety; the larvae and the young animals feed mainly on rotifers, microcrustaceans (mainly copepods) and other small invertebrates, while the adults explore more the groups of microcrustaceans, chironomidae and nematodes, in addition to organic detritus and sand grains (Nico et al. 1996). According to Agostinho et al. (2004) this species is considered migratory of short distances or sedentary, with parental care.

The springs of the Peixe River (Figure 1) are located in the municipality of Torre de Pedra (SP), in the area along the Cuesta Basáltica Environmental Preservation Area (Área de Preservação Ambiental - APA) in Botucatu. The river comprises a drainage sub-basin, equivalent to $584.0 \mathrm{Km}^{2}$ in the direction of the South-North axis and flows into the Tiete River, in a location a little after the Barra Bonita Reservoir (Caramaschi 1986).

The issue concerning the global biodiversity has been widely discussed nowadays, and some authors have defended the study of the parasite species as a fundamental part of it and the least studied group since there is a deficit in the studies about systematic and parasite biodiversity in the world (Brooks and Hoberg 2001, Poulin and Morand 2004). Parasites are indicative of several biological aspects of their hosts, including their diet, migration, recruitment and phylogeny, but they can also be direct indicators of the environmental quality (Galli et al. 2001). Areas under the influence of different environmental impacts may cause changes in the population dynamics of the fish fauna, affecting directly the parasite populations, regarding the prevalence and size of their infrapopulations (Pavanelli et al. 2004). Parasites manifest environmental changes faster than their hosts do (Silva-Souza et al. 2006), and these environmental changes affect the parasites in several manners. The increase or the decrease of the parasitism can indicate anthropic actions that are benefiting the development of some life phase of the parasites and hosts (Lafferty 1997).

The effects of pollution on parasites may be positive or negative: pollution may increase parasitism, or it may be fatal for certain parasite species, leading to a decrease in parasitism (Sures 2005). For heteroxenous metazoan parasites, environmental conditions must be favorable for all host levels (intermediate and final hosts) and for eventually free living stages of the parasites. For monoxenous metazoans, only the ecological demands of the host and the parasite must be fulfilled. Parasites with direct life cycles are normally ectoparasites. Parasites with direct life cycles are in permanent contact with the water and are; therefore, likely to have developed a resistance to changes in water quality. Differences in the susceptibility of heteroxenous and monoxenous parasites can be used to indicate environmental pollution by calculating the ratio of the sums of heteroxenous and monoxenous $(\mathrm{H} / \mathrm{M})$ parasite individuals per host, as well as the ratio of heteroxenous and monoxenous parasite species richness found on the host fish $\left(\mathrm{S}_{\mathrm{H}} / \mathrm{S}_{\mathrm{M}}\right)$ (Sures 2005).

Based on this perspective, this study aimed to develop a study of the parasitic communities of the $H$. litorale, collected in two locations of the Peixe River with different limnological and environmental characteristics.

\section{MATERIALS AND METHODS}

Sixty specimens of $H$. littorale were collected from the Peixe River in the municipality of Anhembi, State of São Paulo, Brazil. An amount of 30 specimens were collected in each locality, from January and July, 2012. The sampling sites were selected on the basis of different environmental and limnological characteristics. The first sampling site is known as Lagoa da Cabeça de Boi (2249'50.7”' S $-048^{\circ} 06^{\prime} 37.0^{\prime \prime} \mathrm{W}$ ) and the second one is the Mouth 


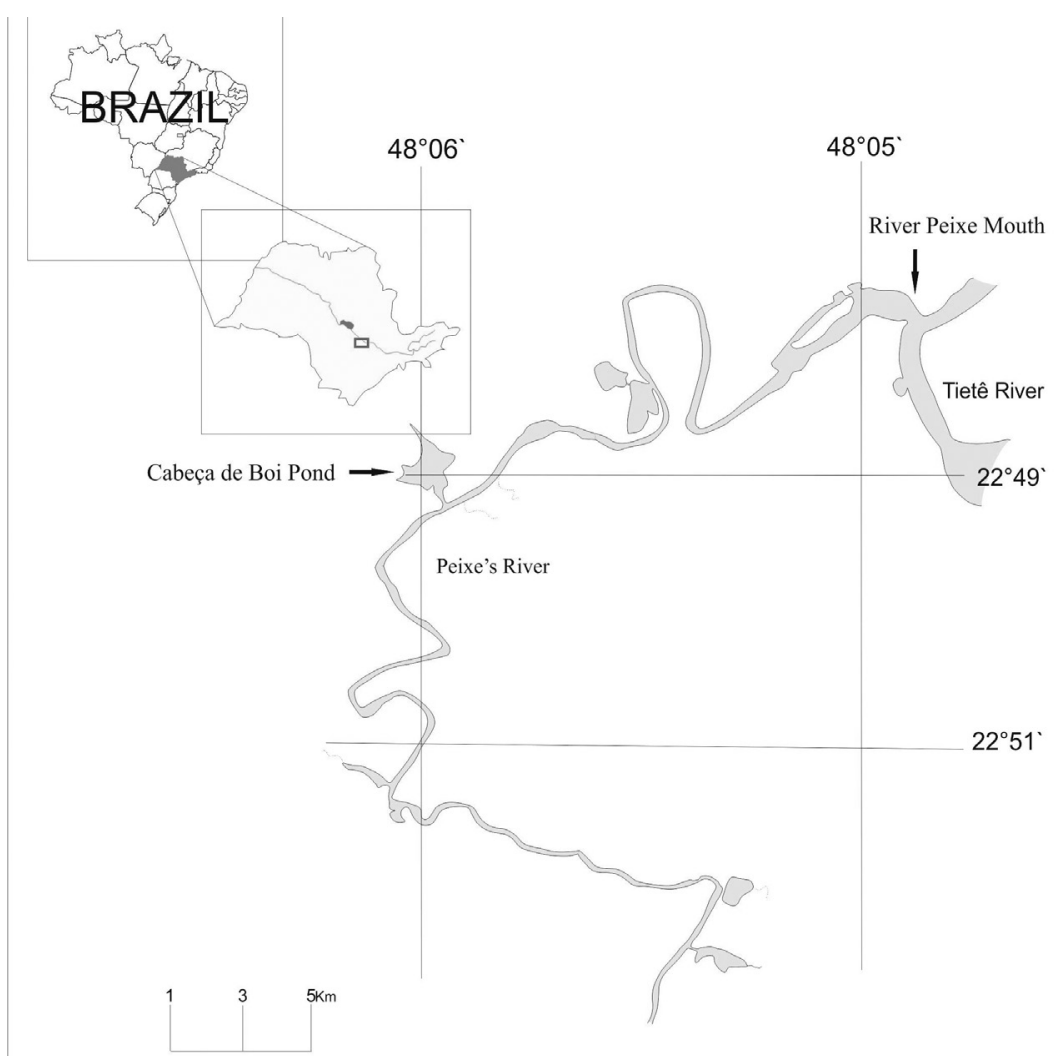

Figure 1 - Map of study area, showing details of river and their geographic coordinates.

of the Peixe River (2249'14.2" S - $048^{\circ} 05^{\prime} 03.0^{\prime \prime}$ $\mathrm{W})$, at an altitude of 480 metres. The Lagoa Cabeça de Boi is a marginal pond that is connected to the channel of the Peixe River and also receives water from two streams, Baiano and Lombardi. It presents low occurrence or absence of aquatic plants, presenting a large amount of submerged tree trunks that appear in the drier period. The surrounding area has remnants of riparian vegetation and grass. The mouth corresponds to a transition region, where the Peixe River flows into the Tietê River, the Barra Bonita dam. It presents banks of aquatic weeds and grass, especially in the shallower coastal region. In the surroundings, there are soil cultivation practices (monocultures of sugarcane and orange), cattle breeding and abundance of waterfowl; in addition to much garbage in the river bed and its banks, such as styrofoam, plastic bottles, plastic bags, mainly in days after heavy rains (Paes 2010). Specimens collected in the Lagoa da Cabeça de Boi presented an average weight of $124.9 \pm 53.7 \mathrm{~g}$ and an average length of $14.3 \pm 2.6 \mathrm{~cm}$. Specimens collected in the Mouth of the Peixe River presented an average weight of $113.5 \pm 50.6 \mathrm{~g}$ and an average length of $14.3 \pm 2.5 \mathrm{~cm}$.

To assess the limnological characterization of the locations studied, we collected water samples in each sample point where the nets were placed for the fish sampling. At each fish collection, a new water sample was taken. The following physicochemical factors of the water were assessed in situ in each collection: transparency (by means of the Secchi disk), dissolved oxygen, temperature, electric conductivity and $\mathrm{pH}$ - obtained through a Horiba multi-sensor device. In the same points, we also collected samples of water through the Van Dorn bottle. The samples were transferred to 5-liter-gallons, which were previously identified regarding the sample point for the analyses of total phosphorus and ammonia levels (Henry and 
Nogueira 1999), nitrite and nitrate (Golterman et al. 1978).

Parasite prevalence, intensity, and abundance were calculated according to Bush et al. (1997). Parasites were classified according to their prevalence in the core species (prevalence higher than $66.66 \%$ ), secondary species (prevalence from 33.33 to $66.66 \%$ ) and satellite species (prevalence lower than $33.33 \%$ ) with the aim of verifying the Importance Value, i.e., the importance of each species in the helminth parasite community (Bush and Holmes 1986). For those parasite species with a prevalence higher than $10 \%$, common in the two locations, the Student $t$-test on $\log (\mathrm{x}+$ 1) transformed data was used to test significant differences of parasite abundance in the two locations (Zar 1999). The variance of mean ratio of parasite abundance (index of dispersion) was used to determine spatial distribution patterns (Ludwig and Reynolds 1988). The frequency of dominance and relative dominance (number of specimens of one species/total number of specimens of all species in the infracommunity) of each parasite species were calculated according to Rohde et al. (1995). The Spearman's rank correlation coefficient $r s$ was calculated to determine possible correlations between the host's total body length and abundance of parasites and between the host's total weight and abundance of parasites 1999. The analysis included only parasite species with a prevalence greater than $10 \%$ (Bush et al. 1997). The following community descriptors were calculated at the infracommunity level: number of parasite individuals (total abundance), species richness, Brillouin's diversity index (log 10 based), evenness associated with Brillouin's diversity index and Margalef's richness index. The effects of the two locations on the community descriptors were evaluated using the Student's $t$-test on $\log$ $(x+1)$ transformed data (abundance) (Zar 1999). The ratio of the heteroxenous and monoxenous parasite species richness $\left(\mathrm{S}_{\mathrm{H}} / \mathrm{S}_{\mathrm{M}}\right)$ were calculated as suggested by Diamant et al. (1999) for each location. According to these authors, higher values are expected in parasitic communities of fish collected in ecologically stable habitats. The statistical significance level was established at $p$ $<0.05$. The ecological terminology follows Bush et al. (1997). Voucher specimens of helminthes were deposited in the Coleção Helmintológica do Instituto de Biociências, Botucatu, (CHIBB), in the State of São Paulo, Brazil.

\section{RESULTS}

Nine species of metazoan parasites were collected (Tables II and III). All fishes were parasitized by at least one species of metazoan parasite. A total of 825 specimens was collected, being 514 in the Lagoa da Cabeça de Boi and 311 in the Mouth of

TABLE I

Environmental characterization of the sampling stations in the lower course of the Peixe River, municipality of Anhembi (SP), under the influence of the Barra Bonita Reservoir (middle Tietê), during the collection period.

\begin{tabular}{ccc}
\hline Parameters & Pond & Mouth \\
\hline Ammonia $(\mathrm{mg} / \mathrm{L})$ & 0.023 & 0.028 \\
Nitrate $(\mathrm{mg} / \mathrm{L})$ & 0.017 & 0.043 \\
Nitrite $(\mathrm{mg} / \mathrm{L})$ & 0.0008 & 0.001 \\
Total phosphorus & 0.034 & 0.029 \\
$(\mathrm{mg} / \mathrm{L})$ & & \\
DO (Dissolved & $8.63 \pm 0.64$ & $7.78 \pm 0.50$ \\
oxygen) $(\mathrm{mg} / \mathrm{L})$ & $(4.30-14.10)$ & $(3.80-12.40)$ \\
& $12.96 \pm 0.92$ & $34.80 \pm 4.15$ \\
Electrical conductivity & $(8.60-20.80)$ & $(9.50-66.40)$ \\
$(\mu \mathrm{S} / \mathrm{cm})$ & & \\
& $0.64 \pm 0.07$ & $0.59 \pm 0.09$ \\
Secchi disc & $(0.22-1.10)$ & $(0.10-1.15)$ \\
transparency $(\mathrm{m})$ & $6.19 \pm 0.39$ & $5.83 \pm 0.47$ \\
& $(2.50-7.60)$ & $(1.50-8.36)$ \\
pH & & \\
& $23.38 \pm 0.95$ & $24.36 \pm 0.77$ \\
Temperature & $(17.60-27.33)$ & $(19.80-28.86)$
\end{tabular}

Values: mean \pm standard deviation (min-max) obtained between January and July 2012. 
TABLE II

Prevalence, mean abundance, mean intensity and site of infection of the metazoan parasites of Hoplosternum littorale (Hancock 1828) collected in the Lagoa Cabeça de Boi of the Peixe River, Middle Tietê, São Paulo, Brazil. s= standard deviation.

\begin{tabular}{|c|c|c|c|c|c|}
\hline Parasites & $\begin{array}{c}\text { Prevalence } \\
(\%)\end{array}$ & Mean Abundance \pm s & $\begin{array}{c}\text { Mean } \\
\text { Intensity } \pm \mathbf{s}\end{array}$ & $\begin{array}{c}\text { Site of infection/ } \\
\text { infestation }\end{array}$ & $\begin{array}{c}\text { Species } \\
\text { importance* }\end{array}$ \\
\hline \multicolumn{6}{|l|}{ Cestoda } \\
\hline $\begin{array}{l}\text { Proteocephalus sp. } \\
\quad \text { (plerocercoid) }\end{array}$ & 3.3 & $0.03 \pm 5.08$ & $1.00 \pm 5.08$ & Intestine & $\mathrm{Sa}$ \\
\hline \multicolumn{6}{|l|}{ Digenea } \\
\hline $\begin{array}{l}\text { Austrodiplostomum } \\
\text { compactum }\end{array}$ & 33.3 & $12.7 \pm 0.35$ & $38.2 \pm 1.07$ & $\begin{array}{l}\text { Intestine, } \\
\text { stomach, liver } \\
\text { and eyes }\end{array}$ & $\mathrm{Se}$ \\
\hline $\begin{array}{c}\text { Magnivitellinum } \\
\text { corvitellinum }\end{array}$ & 43.3 & $1.33 \pm 0.02$ & $3.07 \pm 0.04$ & $\begin{array}{l}\text { Intestine and } \\
\text { stomach }\end{array}$ & $\mathrm{Se}$ \\
\hline \multicolumn{6}{|l|}{ Hirudinea } \\
\hline Glossiphoniidae gen. sp. & 30.0 & $1.8 \pm 0.46$ & $4.9 \pm 1.52$ & Gills & $\mathrm{Se}$ \\
\hline $\begin{array}{c}\text { Placobdella sp. } \\
\text { Monogenea }\end{array}$ & 3.3 & $0.13 \pm 0.19$ & $4.00 \pm 5.64$ & Gills & $\mathrm{Sa}$ \\
\hline Gyrodactylus sp. & 13.3 & $0.53 \pm 0.05$ & $4.00 \pm 0.38$ & Gills and surface & $\mathrm{Sa}$ \\
\hline Scleroductus sp. & 10.0 & $0.10 \pm 0.00$ & $1.00 \pm 0.00$ & Gills and surface & $\mathrm{Sa}$ \\
\hline \multicolumn{6}{|l|}{ Myxozoa } \\
\hline Henneguya guanduensis & 10.0 & $X$ & $\mathrm{X}$ & Gills and stomach & $\mathrm{Sa}$ \\
\hline $\begin{array}{c}\text { Nematoda } \\
\text { Capillaria } \\
\text { (Neocapillaria) } \\
\text { pterophylli }\end{array}$ & 36.6 & $0.46 \pm 0.24$ & $1.27 \pm 1.03$ & $\begin{array}{l}\text { Intestine and } \\
\text { stomach }\end{array}$ & $\mathrm{Se}$ \\
\hline
\end{tabular}

*Species importance based on prevalence: Co, core species (prevalence higher than 66.66\%); Se, secondary species (prevalence from 33.33 to $66.66 \%$ ); Sa, satellite species (prevalence lower than $33.33 \%$ ).

TABLE III

Prevalence, mean abundance, mean intensity and site of infection of the metazoan parasites of Hoplosternum littorale (Hancock 1828) collected in the Mouth of the Peixe River, Middle Tietê, São Paulo, Brazil. s= standard deviation.

\begin{tabular}{|c|c|c|c|c|c|}
\hline Parasites & $\begin{array}{c}\text { Prevalence } \\
(\%)\end{array}$ & Mean Abundance $\pm \mathbf{s}$ & Mean Intensity \pm s & $\begin{array}{c}\text { Site of infection/ } \\
\text { infestation }\end{array}$ & $\begin{array}{c}\text { Species } \\
\text { importance* }\end{array}$ \\
\hline \multicolumn{6}{|l|}{ Digenea } \\
\hline $\begin{array}{l}\text { Austrodiplostomum } \\
\text { compactum }\end{array}$ & 18.2 & $0.23 \pm 0.01$ & $1.25 \pm 0.1$ & $\begin{array}{l}\text { Intestine, } \\
\text { stomach, liver } \\
\text { and eyes }\end{array}$ & $\mathrm{Sa}$ \\
\hline $\begin{array}{c}\text { Magnivitellinum } \\
\text { corvitellinum }\end{array}$ & 36.4 & $1.77 \pm 0.23$ & $4.90 \pm 0.83$ & $\begin{array}{l}\text { Intestine and } \\
\text { stomach }\end{array}$ & $\mathrm{Se}$ \\
\hline \multicolumn{6}{|l|}{ Hirudinea } \\
\hline Placobdella sp. & 18.2 & $1.22 \pm 0.29$ & $6.75 \pm 1.6$ & Gills & $\mathrm{Sa}$ \\
\hline \multicolumn{6}{|l|}{ Monogenea } \\
\hline Gyrodactylus sp. & 63.6 & $9.59 \pm 0.68$ & $15.1 \pm 0.93$ & Gills and surface & $\mathrm{Se}$ \\
\hline Scleroductus sp. & 22.7 & $0.36 \pm 0.06$ & $1.6 \pm 0.27$ & Gills and surface & $\mathrm{Sa}$ \\
\hline Myxozoa & & & & & \\
\hline Henneguya guanduensis & 31.8 & $X$ & $\mathrm{X}$ & $\begin{array}{l}\text { Gills and } \\
\text { stomach }\end{array}$ & $\mathrm{Sa}$ \\
\hline
\end{tabular}

*Species importance based on prevalence: Co, core species (prevalence higher than $66.66 \%$ ); Se, secondary species (prevalence from 33.33 to $66.66 \%$ ); Sa, satellite species (prevalence lower than $33.33 \%$ ). 
TABLE IV

Frequency of dominance, dominance and dispersion index (DI) of the metazoan parasites of Hoplosternum littorale

(Hancock 1828), collected in the Lagoa Cabeça de Boi of the Peixe River, Middle Tietê, São Paulo, Brazil.

\begin{tabular}{|c|c|c|c|}
\hline & ancy & & \\
\hline Parasites & $\begin{array}{c}\text { of } \\
\text { dominance } \\
(\%)\end{array}$ & Dominance & DI \\
\hline
\end{tabular}

Glossiphoniidae gen. sp.

4.5

$0.10 \pm 0.30$

88.2

Austrodiplostomum compactum

$0.75 \pm 0.24$

208.0

Magnivitellinum
corvitellinum

13.5

$0.07 \pm 0.01$

0.75

Gyrodactylus sp.

3.3

$0.03 \pm 0.03$

9.98

Scleroductus sp.

9.0

$0.005 \pm 0$

0.0

Capillaria

(Neocapillaria)

pterophylli
Gyrodactylus sp.

45.4

$0.68 \pm 0.45$

20.6

TABLE V

Frequency of dominance, dominance and dispersion index (DI) of the metazoan parasites of Hoplosternum littorale (Hancock 1828), collected in the Mouth of the Peixe River, Middle Tietê, São Paulo, Brazil.

\begin{tabular}{cccc}
\hline Parasites & $\begin{array}{c}\text { Frequency } \\
\text { of } \\
\text { dominance } \\
\mathbf{( \% )}\end{array}$ & Dominance & DI \\
\hline $\begin{array}{c}\text { Austrodiplosto- } \\
\text { mumcompactum }\end{array}$ & 13.5 & $0.02 \pm 0.02$ & 1.17 \\
$\begin{array}{c}\text { Magnivitellinum }- \\
\text { corvitellinum }\end{array}$ & 23.3 & $0.125 \pm 0.15$ & 7.73 \\
& & & \\
Placobdella sp. & 0 & $0.09 \pm 0.19$ & 10.0
\end{tabular}

Scleroductus sp.

0

$0.03 \pm 0.03$

2.25

TABLE VI

Values of the correlation coefficient by the Spearman $r$ s to assess possible correlations between the parasitic abundance and the total length of Hoplosternum littorale (Hancock 1828), the parasitic abundance and the weight of these hosts collected in the Peixe River, Middle Tietê River, São Paulo, Brazil.

\begin{tabular}{|c|c|c|c|c|}
\hline \multirow[t]{2}{*}{ Parasites } & \multicolumn{2}{|c|}{ Parasitic abundance $X$ total length } & \multicolumn{2}{|c|}{ Parasitic abundance $X$ weight } \\
\hline & $\begin{array}{l}\text { Mouth of the } \\
\text { Peixe River }\end{array}$ & Cabeça de Boi Pond & $\begin{array}{l}\text { Mouth of the } \\
\text { Peixe River }\end{array}$ & Cabeça de Boi Pond \\
\hline & $\mathbf{r}_{\mathrm{s}}$ & $\mathbf{r}_{\mathrm{s}}$ & $\mathbf{r}_{\mathrm{s}}$ & $\mathbf{r}_{\mathrm{s}}$ \\
\hline \multicolumn{5}{|l|}{ Digenea } \\
\hline Austrodiplostomum compactum & -1.86 & 0.09 & -1.09 & 0.09 \\
\hline Magnivitellinum corvitellinum & 0.26 & 0.06 & -0.49 & 0.07 \\
\hline \multicolumn{5}{|l|}{ Hirudinea } \\
\hline Glossiphoniidae gen. sp. & -0.01 & $\mathbf{X}$ & 0.91 & $\mathbf{X}$ \\
\hline Placobdella sp. & $\mathbf{X}$ & 0.18 & $\mathbf{X}$ & 0.21 \\
\hline \multicolumn{5}{|l|}{ Monogenea } \\
\hline Gyrodactylus sp. & 0.30 & $0.31 *$ & 0.78 & 0.34 \\
\hline Scleroductus sp. & -0.20 & 0.18 & -1.07 & 0.23 \\
\hline \multicolumn{5}{|l|}{ Nematoda } \\
\hline Capillaria (Neocapillaria) pterophylli & -0.43 & $\mathbf{X}$ & -0.67 & $\mathbf{X}$ \\
\hline
\end{tabular}

* Significant correlation between the length and the parasitic abundance with $p=0.02$ 
TABLE VII

Brillouin's diversity index $(H)$, Pielou's evenness index $(J ')$ and Margalef's richness index (d) of the metazoan parasites of Hoplosternum littorale (Hancock 1828) in the Peixe River, Middle Tietê River, São Paulo, Brazil.

\begin{tabular}{lcccc}
\hline $\begin{array}{c}\text { Points } \\
\text { of the } \\
\text { river }\end{array}$ & $\boldsymbol{H}$ & $\mathbf{J}$, & $\mathbf{d}$ & $\mathbf{S}_{\mathbf{H}} / \mathbf{S}_{\mathbf{M}}$ \\
\hline $\begin{array}{c}\text { Mouth } \\
\text { of the } \\
\text { Peixe }\end{array}$ & $0.99 \pm 0.74$ & $0.87 \pm 0.09$ & $1.54 \pm 0.65$ & 1.00 \\
$\begin{array}{l}\text { River } \\
\text { Cabeça } \\
\text { de Boi }\end{array}$ & $1.03 \pm 0.53$ & $0.86 \pm 0.12$ & $1.73 \pm 1.01$ & \\
Pond & & & & \\
\hline
\end{tabular}

TABLE VIII

Values of the Student t-test for the comparisons of abundance of the component parasite species of Hoplosternum littorale (Hancock 1828) from two locations in the Peixe River, Middle Tietê River, São Paulo State, Brazil.

\begin{tabular}{ccc}
\hline Parasites & $\mathbf{t}$ & $\mathbf{p}$ \\
\hline Austrodiplostomum compactum & 2.88 & 0.008 \\
Magnivitellinum corvitellinum & -1.0 & 0.32 \\
Gyrodactylus sp. & -3.46 & 0.002 \\
Scleroductus sp. & -1.36 & 0.18 \\
Richness & 1.0 & 0.32 \\
Mean species richness & 1.18 & 0.25 \\
Mean total abundance & -1.34 & 0.19 \\
Brillouin's diversity index & -1.50 & 0.17 \\
Pielou's evenness index & 0.01 & 1.00 \\
Margalef's richness index & -0.94 & 0.37 \\
\hline
\end{tabular}

TABLE IX

Characteristics of the metazoan parasites infracommunities found in Hoplosternum littorale (Hancock 1828) from two locations in the Peixe River, Middle Tietê River, São Paulo State, Brazil. $t=$ values of the Student t-test for the comparison between the two locations.

\begin{tabular}{ccc}
\hline Characteristics & t & p \\
\hline Mean species richness & 1.18 & 0.25 \\
Mean total abundance & -1.34 & 0.19 \\
Brillouin's diversity index & -1.50 & 0.17 \\
Pielou's evenness index & 0.01 & 1.00 \\
Margalef's richness index & -0.94 & 0.37 \\
\hline
\end{tabular}

the Peixe River, with an average total abundance of $17.14 \pm 1.00$ and $10.36 \pm 0.58$, respectively. All species collected in the Mouth of the Peixe River were present in the Lagoa da Cabeça de Boi. In the Lagoa da Cabeça de Boi, the parasite that presented the greatest dominance frequency was the monogenetic Gyrodactylus sp. while, in the Mouth of the Peixe River, it was the digenetic Austrodiplostomum compactum (Tables IV and V). Except for the Magnivitellinum corvitellinum and Scleroductus sp., which presented a regular distribution pattern in the Lagoa da Cabeça de Boi, the other parasites presented a typical pattern of aggregated distribution (Tables IV and V). The monogenetic Gyrodactylus sp. presented a positive correlation between its abundance and the total length of the host in the Mouth of the Peixe River ( $r s=-0.31, \mathrm{P}=0.02$ ), and the other parasites did not present any significant correlation. The weight of the $H$. littorale did not influence the parasitism in any of the points (Table VI). The species Glossiphoniidae gen. sp., Austrodiplostomum compactum, Magnivitellinum corvitellinum and Capillaria (Neocapillaria) pterophylli were classified as secondary in the Lagoa da Cabeça de Boi, and the species Magnivitellinum corvitellinum and Gyrodactylus sp. were classified as secondary in the Mouth of the Peixe River; all others were classified as satellite (Tables II and III). Comparing the specimens in common in the two points, statistically significant differences were found in the abundance of Austrodiplostomum compactum and Gyrodactylus sp. (Table VIII).

Both Brillouin`s diversity index and Margalef"s richness index were greater in the Lagoa Cabeça de Boi (Table VII). There was no significant difference between the mean species richness, mean total abundance. The Brillouin's diversity index, the Pielou's evenness index and the Margalef's richness index in the two collected locations (Table IX). The ratio of heteroxenous and monoxenous parasite species richness (SH/SM) was higher in 
the Lagoa Cabeça de Boi. There was a significant difference in the nitrate $(p=0.023)$, nitrite $(p=0.015)$ electric conductivity $(p=0.025)$ between the Peixe River's mouth and pond. The highest values were found in the mouth (Table II).

\section{DISCUSSION}

The results of the physicochemical analysis of the water showed the mouth of the Peixe River can be considered an area that suffers more from anthropogenic actions than the Lagoa da Cabeça de Boi (Table I) and; therefore, it is slightly more affected. These results can be associated with the fact that this point is already influenced by the Tietê River and by other impacts, as previously explained, since the increase of the ions studied in this research, in water bodies, can be a result of anthropogenic actions. We can highlight the use of fertilizers and nitrogen inputs that are largely used in the agriculture (Barbosa 2005).

The parasitic community of $H$. littorale was characterized in the two points by a high richness and diversity. According to Bush et al. (1997), diversity is the concept that describes the composition of a community in terms of the number of species and some factor that weighs the relative equality of the distribution of each species. In no environment, all species are equally common; some are very abundant, others are moderately common and the majority is rare. In the Lagoa da Cabeça de Boi, the richness of species and the abundance of the heteroxenous parasites are superior compared to the ones found in the Mouth of the Peixe River. According to Sures (2005), the adverse environmental conditions, such as the water pollution, might have deleterious effects on intermediate hosts of heteroxenous parasites and, thus, reduce the parasite abundance. Consequently, populations of such monoxenous parasites are expected to be less affected by the change of environmental conditions compared to heteroxenous parasites. That also justifies the fact there is a significant difference between the abundances and the dominance of Austrodiplostomum compactum and Gyrdactylus sp. in the two points.

According to Luque et al. (2004), in fish, some comparative studies have shown the size of the body of the host is a good preview of the richness of the parasite species, while others do not show any effect of the length in the parasitic richness. The monogenetic Gyrodactylus sp. presented a positive correlation between its abundance and its hosts length. Based on the arguments of the biogeographic islands theory, bigger hosts can accommodate more species of parasites than the minors; therefore, they can have an increased exposition to external parasites due to its bigger area of surface, which facilitates the contact with the infecting periods (Luque et al. 2004).

Except for the Magnivitellinum corvitellinum and Scleroductus sp., which presented a uniform distribution pattern, all the other parasites presented the aggregate pattern of distribution. This pattern is considered typical in the parasites of freshwater fish. According to Zuben (1997), the aggregate pattern of distribution acts to increase the dependent regulation of the density and the abundance of both hosts and parasites, besides reducing the level of interspecific competition between the parasites.

The mixozoary Henneguya guanduensis was described by Abdallah et al. (2007) parasitizing the gills of this host in the Guandu River; however, in the Peixe River, this parasite was found in the gills and stomach.

Proteocephalus sp., Gyrodactylus sp., Scleroductus sp. and Capillaria (Neocapillaria) pterophylli are being registered for the first time in this host.

\section{REFERENCES}

ABDALLAH VD, AZEVEDO RK, LUQUE JL AND BOMFIM TCB. 2007. Two new species of Henneguya Thélohan, 1892 (Myxozoa, Myxobolidae), parasitic on 
the gills of Hoplosternum littorale (Callichthyidae) and Cyphocharax gilbert (Curimatidae) from the Guandu River, State of Rio de Janeiro, Brazil. Parasitol Latinoam 62: $35-41$.

AGOSTINHO AA, GOMES LC, VERÍSSIMO S AND OKADA EK. 2004. Flood regime, dam regulation and fish in the Upper Paraná River: effects on assemblage attributes, reproduction and recruitment. Rev. Fish Biol. Fish. 14: 11-19.

BARBOSA CF. 2005. Hidrogeoquímica e a contaminação por nitrato em água subterrânea no bairro Piranema, Seropédica-RJ. (MSc Thesis), Brazil: Universidade Estadual de Campinas. (Unpublished).

BROOKS DR AND HOBERG EP. 2001. Parasite systematics in the $21^{\text {st }}$ century: opportunities and obstacles. Trends Parasitol. 17: 273-275.

BUSH AO AND HOLMES JC. 1986. Intestinal helminths of lesser scaup ducks: an interactive community. Can J Zool 64: 142-152.

BUSH AO, LAFFERTY KD, LOTZ JM AND SHOSTAK AW. 1997. Parasitology meets ecology on its own terms: Margolis et al. revisited. J Parasitol 83: 575-583.

CARAMASCHI EP. 1986. Distribuição da ictiofauna de riachos das Bacias do Tietê e do Paranapanema, junto ao divisor de águas (Botucatu, SP). 1986. (PhD Thesis), Brazil: Universidade Federal de São Carlos.

DIAMANT A, BANET A, PAPERNA I, WESTERNHAGEN HV, BROEG K, KRÜNER G, KÖRTING W AND ZANDER S. 1999. The use of fish metabolic, pathological and parasitological indices in pollution monitoring. II. The Red Sea and Mediterranean. Helgol Mar Res 53: 195-208.

GALLI P, CROSA G, MARINIELLO L, ORTIS M AND D'AMELIO S. 2001. Water quality as a determinant of the composition of fish parasites communities. Hydrobiologia 452: 173-179.

GOLTERMAN HL, CLYMO RS AND OHNSTAD R. 1978. Methods for clorophyl and phaepgments determination. Archiv für Hydrobiologie 14: 14-36.

HAHN NS, ALMEIDA VLL AND LUZ KDG. 1997. Alimentação e ciclo alimentar diário de Hoplosternum littorale (Hancock) Siluriformes, (Callichthyidae) nas Lagoas Guaraná e Patos da Planície do alto Rio Paraná, Brasil. Rev Bras Zool 14: 57-64.

HENRY R AND NOGUEIRA MG. 1999 A Represa de Jurumirim (São Paulo): Primeira síntese sobre o conhecimento limnológico e uma proposta preliminar de manejo ambiental. In: Henry R (Ed), Ecologia de reservatórios: estrutura, função e aspectos sociais. FapespFundibio, Botucatu, p. 651-685.

LAFFERTY KD. 1997. Environmental parasitology: what can parasites tell us about human impacts on the environment? Parasitol Today 13: 251-255.
LUDWIG JAAND REYNOLDS JF. 1988. Statistical Ecology: A Primer on Methods and Computing. New York, WileyInterscience Publications, $337 \mathrm{p}$.

LUQUE JL, MOUILLOT D AND POULIN R. 2004. Parasite biodiversity and its determinants in coastal marine teleost fishes of Brazil. Parasitology 128: 671-682.

LUQUET P, BOUJARD T, PLANQUETTE P, MOREAU Y AND HOSTACHE G. 1990. The culture of Hoplosternum littorale: State of the art and perspectives In: Advances in Tropical Aquaculture. (ed. BARRET), p. 511-516.

NICO LG, WALSH SJ AND ROBINS RH. 1996. An introduced population of the South American callichthyid catfish Hoplosternum littorale in the Indian River Lagoon system, Florida. Florida Scientist 59: 189-200.

PAES VJK. 2010. A ictiofauna do rio do Peixe sob a influência da represa de Barra Bonita (SP): índices ecológicos e condições limnológicas. (PhD Thesis). Brazil: Universidade Estadual Júlio de Mesquita Filho.

PAVANELLI GC, MACHADO MH, TAKEMOTO RM, GUIDELLI GM AND LIZAMA MAP. 2004. Helminth fauna of the fishes: diversity and ecological aspects. In: The Upper Paraná River and its Floodplain: Physical aspects, Ecology and Conservation. (org.Thomaz, Agostinho \& Hahn) $1^{\text {st }}$ ed., p. 309-329.

POULIN R AND MORAND S. 2004. Parasite Biodiversity. Washington: Smithsonian Books, 216 p.

REIS RE. 1997. Revision of the neotropical catfish genus Hoplosternum (Ostariophysi: Siluriformes: Callichthyidae), with the description of two new genera and three new species. Ichthyol Explor Freshwat 7: 299326.

ROHDE K, HAYWARD C AND HEAP M. 1995. Aspects of the ecology of metazoan ectoparasites of marine fishes. Int J Parasitol 8: 945-970.

SILVA-SOUZA AT, SHIBATTA AO, MATSUMURATUNDISI T, TUNDISI JG AND DUPAS FA. 2006. Parasitas de peixes como indicadores de estresse ambiental e eutrofização. In: Tundisi JG, Matsumura-Tundisi T and Galli SC (Eds), Eutrofização na América do Sul: causas, conseqüências e tecnologias para gerenciamento e controle. $1^{\mathrm{a}}$ ed., p. 373-386.

SURES B. 2005. Effects of pollution on parasites, and use of parasites in pollution monitoring. In: Rohe K (Ed), Marine Parasitology. CSIRO Publishing, Collingwood, p. 421425.

ZAR JH. 1999. Biostatistical Analysis. New Jersey, PrenticeHall.

ZUBEN CJV. 1997. Implicações da agregação espacial de parasitas para dinâmica populacional na interação hospedeiro parasita. Rev Saúde Pública 31: 523-530. 